\title{
APPLICATION OF INFORMATION TECHNOLOGIES IN THE REGIONALIZATION PROCESSES OF METOHIA
}

DOI: http://dx.doi.org/10.18509/GBP.2016.17

UDC: 004-049.8:528.93]:911(497.115)

\section{Msc Bojana Jandzikovic,}

University of Pristina, with temporary seated in Kosovska Mitrovica, Faculty of Science and Mathematics, Department of Geography.

\begin{abstract}
The territory of Kosovo and Metohija is divided according to many geospatial parameters and characteristics, both physical geographic and socio-economic. The basic division is in physical geography which divides that space into two basins and that Kosovo as one and Metohija as the other.

Modern digital methods (Geographic Information System), artificial intelligencecan determine the ratio of settlementsattraction in Metohija. Gravity model of settlementsattraction and kernel distribution can define the limits of the gravitational influence of the settlements.
\end{abstract}

Keywords: Metohija, GIS, artificial intelligence, gravity model, the kernel distribution.

\section{INTRODUCTION}

The structure of the work is based on the following characteristics: an introduction is followed by a brief description of the physical geographiccharacteristics, social characteristics and finally the application of information technology on the basis of allocation of the village we come to the regionalization of Metohija area.

This study is framed by educational issue of GIS and analysis of geographic and social space of Metohija.

The methods that were used during the researcher present classical methods scientific and researching work: methods of description, analysis, synthesis, classification, statistical and cartographic methods.

The main objective of the research is a representation of the presence of information technology in the process of regionalization [5]. Based on obtained results, guidelines for the improvement of gravitational zones ofsettlements can be formed.

Geographic Information System (GIS) is a system for management of spatial data and associated characteristics [3]. In the strictest sense, it is a computer system which is capable of integration, storing, editing, analysis and display of geographic information. In a broader sense GIS is a tool of "smart map" which leaves room for users to detect geographical differences.

Artificial intelligence is a subfield of computer science. The aim of the researchof artificial intelligence is the development programs (software), which will enable computers to behave in a way that could be characterized as intelligent.

Newton's law of gravity has application in geography because it can clearly determine the migration, the movement of tourists, demographic processes, etc. In this context, the gravity model can serve as an excellent tool for assessing the situation and dynamics in the process of regionalization [1]. 
By hierarchical structure of settlements, with the use of information technology wit will first start from the concept of the impact of gravitational areas of the city [2]. The influence of an area depends mainly on the number of inhabitants and the distance between settlements what is directly related to the law of gravity, which Isaac Newton set.

Based on the given formula we will get a clearer picture of settlements with elements of population density in Metohija.

\section{GEOGRAPHICAL POSITION OF METOHIJA}

Kosovo and Metohija occupy an area of $10.887 \mathrm{~km}^{2}$. It consists of two regional unities, Kosovo in the east and Metohija in the west. Metohija is surrounded by mountains in the north and northwest Kopaonik, Prokletije in the west, Paštrik in the southwest, Šar planina and Drenica in the south and southeast that separates Metohija from Kosovo in the east and northeast.

Metohija is the geographical area that covers an area of $3.891 \mathrm{~km}^{2}$ and 700,577 inhabitants live in this area [8]. At the widest part, Metohija has a width of $23 \mathrm{~km}$, and covers a distance of $60 \mathrm{~km}$. The average altitude is 550 meters.

Landscape of Metohija is extremely rich in natural resources. Metohijska Valley is known for its fertile arable land, black soil, beautiful meadows, rivers, vineyards. Because of its location, temperate continental (parish) climate Metohija is one of the best landscapes for viticulture in the Balkans.

\section{HIERARCHICAL SETTLEMENT SYSTEM OF METOHIJA}

Based on these levels we come to the territorial deployment of settlements, which differ in terms of functional equipment where we come to the hierarchical ranking [6]. The territory is divided into two administrative districts Peć and Prizren.

The District of Peć includes the following municipalities:

1. The municipality of Peć has an area of $603 \mathrm{~km}^{2}$ with a population of 95,723 , a town of Peć, the seat of the district has a population of 48,962 [8],

2. The municipality of Istok has an area of $454 \mathrm{~km}^{2}$ with a population of 39.289 [8],

3. The municipality of Klina has an area of $403 \mathrm{~km}^{2}$ with a population of 38.496 [8],

4. The municipality of Dečani has an area of $402 \mathrm{~km}^{2}$ with a population of 40.019 [8] and

5. The municipality of Đakovica has an area of $254 \mathrm{~km}^{2}$ with a population of 94.158 [8].

The District of Prizren includes the following municipalities:

1. The Municipality of Prizren has an area of $640 \mathrm{~km}^{2}$, with a population of 221.000 , a town Prizren, the seat of the district, has 85,119 inhabitants [8],

2. The municipality of Suva Reka has an area of $361 \mathrm{~km}^{2}$ with a population of 59.722 [8],

3. The Municipality of Mališevo has an area of $306 \mathrm{~km}^{2}$ with a population of 56.000 [8],

4. The municipality of Orahovac has an area of $401 \mathrm{~km}^{2}$ with a population of 55.053[8] and

5. The municipality of Dragaš has an area of $386 \mathrm{~km}^{2}$ with a population of 33.997 [8].

\section{REGIONALIZATION OF METOHIJA IN THE CASE OF INFORMATION TECHNOLOGY AND THE LAW OF GRAVITY}

The application of information systems represents the basic prerequisite for the development of modern scientific disciplines. 
The gravity of minor centers towards larger can be checked by using the formula of field intensity of the demographic impact that is [5] as follows:

$$
\mathrm{E}_{b}^{a}=\frac{H a}{R_{a}^{2}}
$$

Where $E_{b}^{a}$ is the intensity of the demographic impact of the settlement a in the point $b$, Hapopulation of a settlement a, Raa distance between settlementsa and $b$.

On this basis, the system of hierarchical relations between regions [4] can be determined if the following rule is used. The settlement $b$ with its gravity area is located in the impact zone of a larger settlement a, if the intensity of the demographic impact of the settlements $a$ in the point $b$ is greater than the intensity of the impact of other settlement $c$ with in that point.

Prizren-Suva Reka=4479,9 Peć-Istok=1958,5

Prizren-Mališevo=1850,4 Peć-Klina=1632,1

Prizren-Orahovac $=3039,9$ Peć-Dečani $=3497,3$

Prizren-Dragaš $=2503,5$ Peć-Đakovica $=1398,9$

42.9

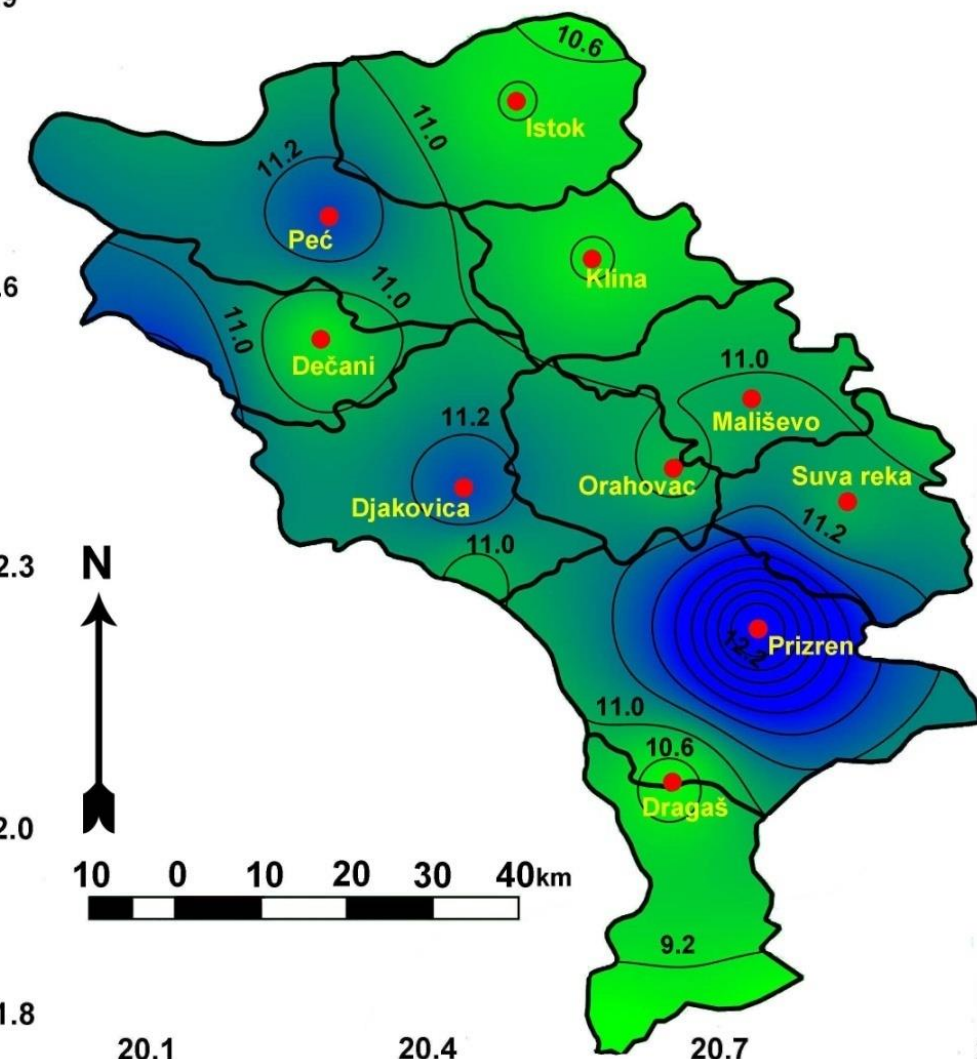

\begin{tabular}{|l|}
\hline Legend \\
$\square$ Metohia \\
Dispersion of populations \\
$20000-40000$ \\
$40000-60000$ \\
$60000-80000$ \\
$80000-100000$ \\
$>100000$ \\
Towns \\
contour line(In) of Pop.
\end{tabular}

42.3

41.8

20.1

20.4

20.7

21.0

21.3

Figure 1. Map of population dispersion in the territory of Metohia. Contour line derived from natural logarithm (ln) multiple with number of population in the given municipality $(\ln ) *$ Pop.

As a measure of the intensity of population we used the density of the population, which represents the quotient of the number of inhabitants and the area where the population lives. Thus we come to the dispersion of the population, depending on the type of 
settlement (compact or scattered type), the size of the settlements and their mutual distances.

\section{CONCLUSION}

Complex regionalizacioni urban and rural systems are made up of several settlements [7], whose integrity arises from the connections arising from the interaction between their conditional structural elements, settlements of different types and different hierarchies. The total number of functional settlements is 585, on the territory of Metohija 10 are grouped within the municipal units (Peć, Prizren, Dečani, Mališevo, Orahovac, Klina, Dragaš, Suva Reka, Istok and Đakovica). The number of inhabitants varies from 10 in the smallest settlement to 85.119 in Prizren, which has the greatest gravitational attraction directed towards other settlements. So with its largest quantity Prizren has the greatest gravitational force.

\section{REFERENCES}

[1] Đerčan B. (2014): Systems of settlements in Srem, Doctoral dissertation, University of Novi Sad, Faculty of Science, Department of Geography and Hotel Management, Novi $\mathrm{Sad}$

[2] Žikić J.: Use of gravitational and potential models for determining the nodal regions in the case of SR Serbia, Slovenia, p. 149-156.

[3] Keith C., Leonard J. (1998): Loose-coupling a cellular automaton model and GIS: long-term urban growth prediction for San Francisco and Washington, International Journal of Geographical Information Science, volume 12, pp 699-714.

[4] Lösch A. (1938): The nature of economic region, The Southern Economic Journal, 5, pp. 71-78.

[5] Merlin P. (1977): Town, the quantitative method for analyzing, Progress, Moscow

[6] Sekur T. (2006): Gravity modeling of regional dispersion FDI, Faculty of Economics, University of Zagreb

[7] Tosic D. (2012): The principles of regionalization, University of Belgrade, Faculty of geography, Belgrade

[8] 2011. Census in Kosovo. 